\title{
Suitability and scenario modeling to support soil and water conservation interventions in the Blue Nile Basin, Ethiopia
}

\author{
Ahmed Amdihun ${ }^{1 *}$, Ephrem Gebremariam', Lisa-Maria Rebelo ${ }^{2}$ and Gete Zeleke ${ }^{3}$
}

\begin{abstract}
Background: The widespread land degradation in Ethiopia has necessitated extensive soil and water conservation interventions over the last four decades. Despite these the degradation of land continues. The conservation interventions in most cases were, and still are, predominantly top-down approaches following government directives. The success of these blanket approaches has been limited and an alternative approach needs to be devised. This paper attempts to identify alternative options for selecting appropriate soil and water conservation technologies based on the biophysical suitability of the landscape.

Results: The results of this study suggest that with appropriate soil and water conservation measures, it is possible to reduce soil loss within the Blue Nile Basin by up to 600 million tons $46 \%$ within 5-10. The statistics on net soil loss reduction also indicate that successful implementation of conservation measures in only four administrative zones (out of 17) can potentially reduce up to $60 \%$ of the total soil loss in the Basin.

Conclusion: Landscape level modeling of soil and water conservation has enabled identification of appropriate conservation measures that can are suited to particular biophysical niches. A targeted approach to soil and water conservation is more efficient in terms of both financing and labour, in contrast to the traditional blanket approaches of the past.
\end{abstract}

Keywords: Soil and water conservation; Landscape suitability; Soil erosion modeling, Blue Nile, Ethiopia

\section{Background}

Land degradation reduces the productivity of agricultural land, and affects the livelihoods of millions of people.

In Ethiopia $84 \%$ of the population lives in rural areas and $95 \%$ of the livelihoods depends on subsistence small scale agriculture. Agriculture constitutes $46.6 \%$ of the national GDP and employs $90 \%$ of the rural population. The average agricultural land holding is nearly one hectare which hardly feeds the average 6.5 persons family size in rural areas (CSA 2008). This creates pressure on the natural resources reduces household income, and results in food insecurity. Eleni (2008) have emphasized that soil degradation is one of the major environmental problems challenging agricultural production in many

\footnotetext{
* Correspondence: ahmed.amdihun@eiabc.edu.et

'Addis Ababa University, EiABC, Chair of CAD and Geo-informatics, P.O. Box 518, Addis Ababa, Ethiopia

Full list of author information is available at the end of the article
}

parts of Ethiopia and highlight the need for conservation action. Although various soil and water conservation interventions have been introduced across Ethiopia, land degradation, mainly in the form of soil erosion, continues to be a serious problem. Soil erosion is frequently cited as one of the most significant challenges to food security and future economic development of the country (Wagayehu and Lars 2003). Soil degradation is a growing problem in Ethiopia and a threat to any future agriculture based growth or 'transformation'.

The Ethiopian Forestry Action Program (EFAP 1994) estimated that every year the Ethiopian Highlands lose between 1.9 to 3.5 billion tons of topsoil and every year $20,000-30,000$ ha of cropland in the highlands is taken out of production as a result of soil erosion. This study also estimated that by 2010, some 10 million highland farmers' cultivation land would be destroyed if land degradation were to continue at the same rate. 
State sponsored soil water conservation (SWC) efforts were begun after the 1970 catastrophic drought and famine. One of the contributions of this large scale intervention was the introduction large scale SWC interventions; both structural and afforestation programs. In total close to one million kilometer length of structures were constructed which had some beneficial effects but were not sustained after the downfall of the "Derg" a regime for various reasons. Some of the common reasons often cited and relevant to this discussions are the use of force in implementing the SWC measures, insufficient participation of farmers in the planning of conservation alternatives and in decisions regarding the selection of technologies. Furthermore, the outcome of the interventions was not rewarding in the short term to farmers. All these were among the top reasons often cited for the failure over the last decades (Bewket 2003; Admassie 2000; Hurni 1997, Kassie et al. 2011).

In order to be successful, soil and water conservation work needs to be participatory. Shiferaw and Holden (1998) argued that conservation measures were traditionally undertaken without the involvement of the land owner. Farmers were not allowed to remove the structures once built although maintenance was often carried out through the Productive Safety Net Program (SNP) with farmer incentives. However, the practice has largely remained delivery oriented in which the farmers are forced to implement conservation measures designed for them by technical experts (Bewket 2003). Unfortunately, farmers experience of SWC techniques, coupled with their knowledge of the land they manage, are often ignored and bypassed in the current top-down approach to conservation. Mitiku et al. (2006) criticized this approach where farmers have typically been offered one conservation package (e.g. terracing) rather than a choice of alternative practices (menu of options) from which to choose those that match their particular needs and circumstances (Admassie 2000; Nowak 1987).

Hurni (1997) developed several possible scenarios and options, highlighting that sustainable land management involves more than mere technological development. Multi-criteria analysis has been used as an approach to combining the most significant factors in choosing appropriate soil and water conservation technologies. Various studies exist which demonstrate the practical application

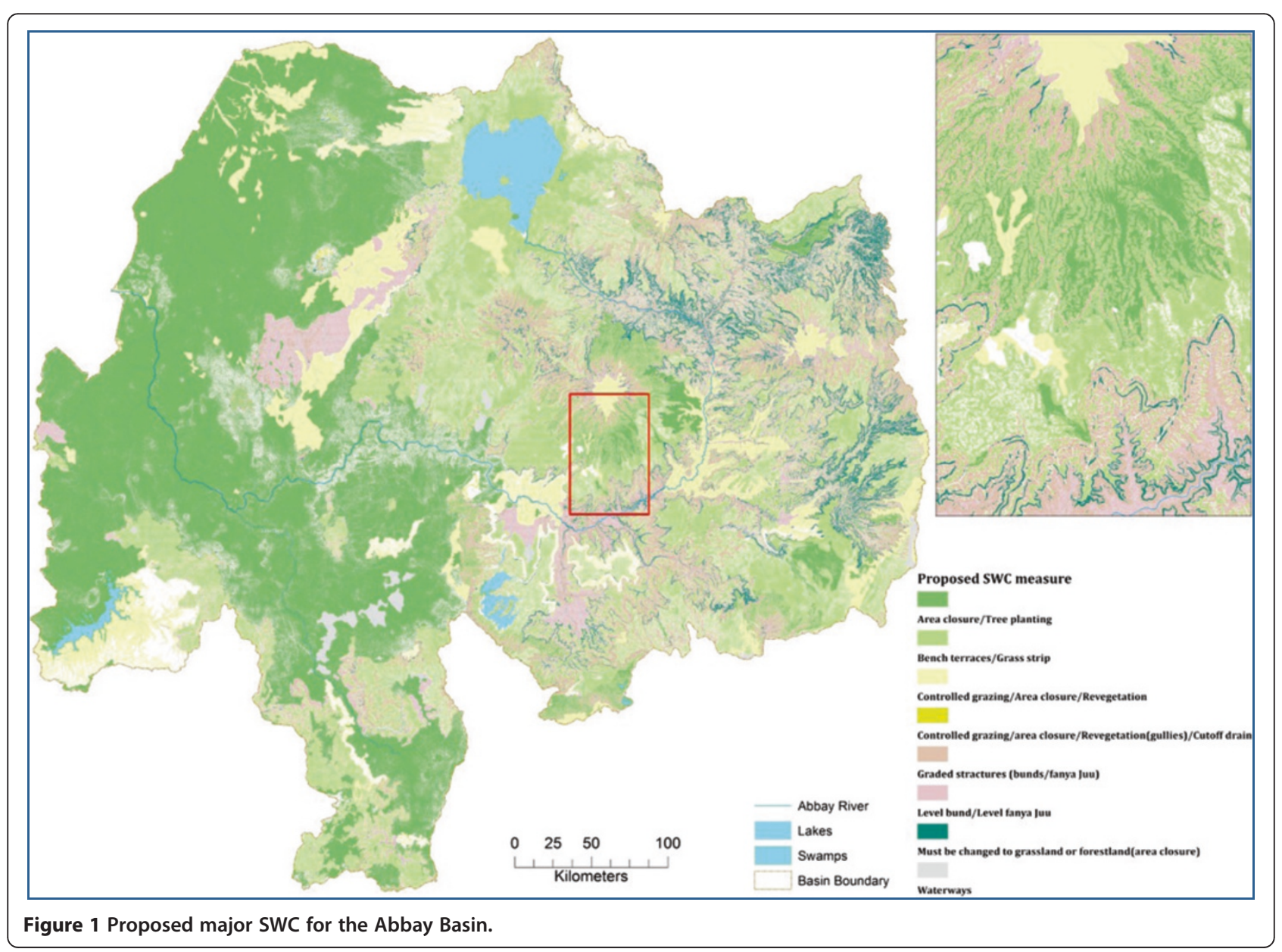


Table 1 Proposed major SWC measures and area coverage (Based on model results)

\begin{tabular}{llll}
\hline Proposed major SWC measure & Code & $\begin{array}{l}\text { Area } \\
\mathbf{( k m}^{2} \mathbf{)}\end{array}$ \\
\hline Bench Terraces/Grass Strips & BT & 49,484 & 27.9 \\
Level bund/Level fanya Juu & LB/LFJ & 11,161 & 6.3 \\
Graded bund/Graded fanya Juu & GB/GFJ & 24,650 & 13.9 \\
Controlled grazing /Revegetation/Cutoff drain & CG/RV/CD & 15,790 & 8.9 \\
Area Closure/Tree planting & AC/TP & 68,928 & 38.9 \\
Must be changed to grassland or Forest land & MCGL/FL & 5,915 & 3.3 \\
Waterways & WW & 1,159 & 0.7 \\
\hline
\end{tabular}

of multi-criteria analysis in natural resource management including for soil and water conservation (Prato and Herath 2007; Robert et al. 2007, Geneletti 2007; Kiker et al. 2005).

The objective of this paper is to demonstrate a landscape level SWC planning approach based on multicriteria spatial analysis. It is also intended to demonstrate the impacts of SWC technologies by out-scaling plot level studies to the bigger landscape (Blue Nile Basin). The major limitation of this work is that it did not consider social acceptance of the technologies assuming that applying the technologies to local settings requires further social considerations based on available resources and experiences.

\section{Result and discussions \\ Proposed SWC measures}

One of the focus areas of this research was to identify optimal SWC options for the different landscapes and land use systems of the Basin based on susceptibility to soil erosion. Some of the key points typically considered in SWC planning are the nature and level of degradation, the agroecology of the area, land use and land cover conditions, slope and soil types. Based on these five biophysical parameters, areas of the Basin are categorized under one of the proposed SWC interventions and a SWC. In total six major types of SWC interventions are identified and proposed for the different landscapes and soil erosion grades of the Blue Nile Basin.

The assumption is that all of the appropriate support practices are implemented together with these major ones. The suitable SWC measures identified for nearly $40 \%$ of the areas in the Blue Nile Basin is area closure

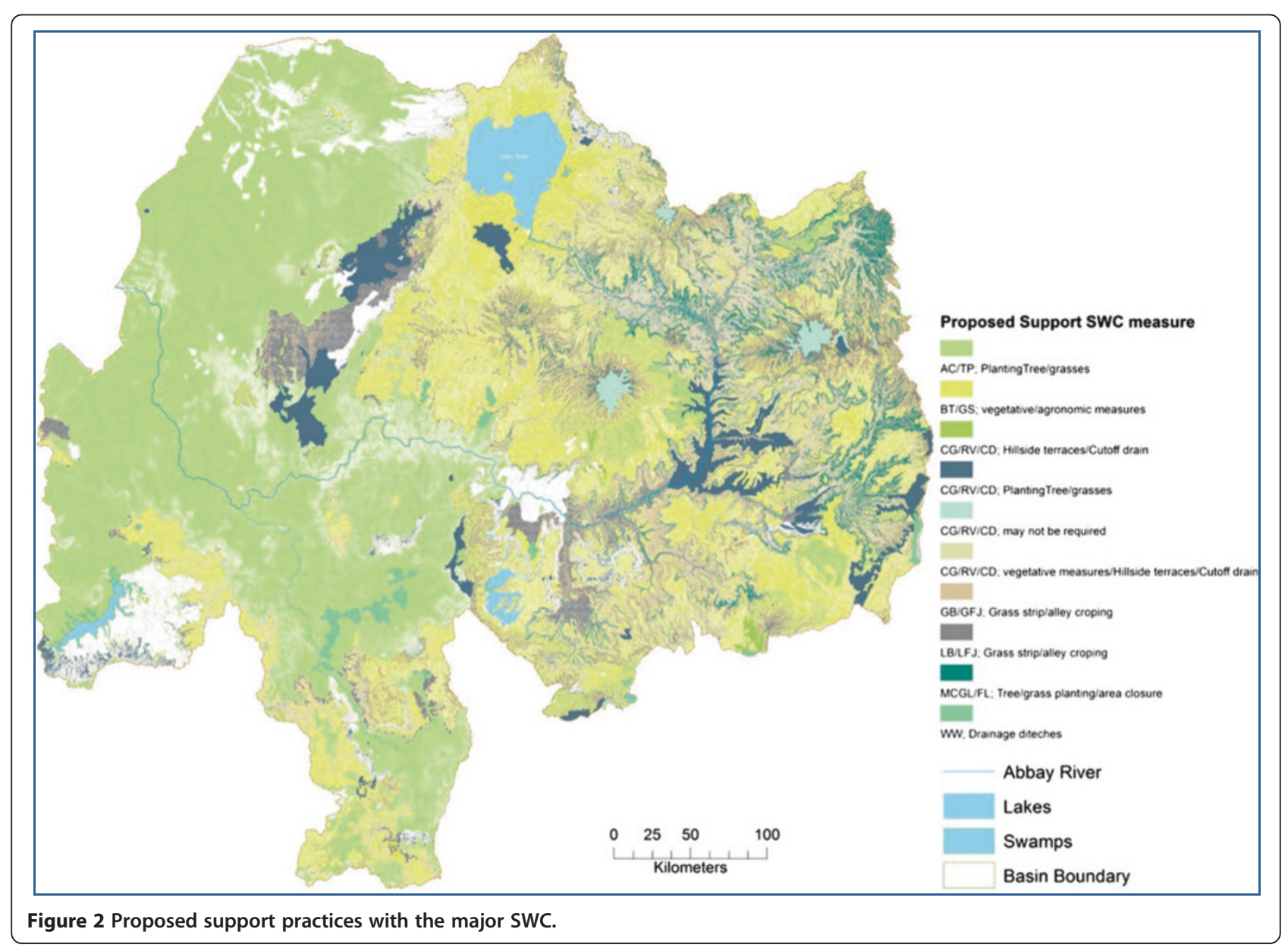




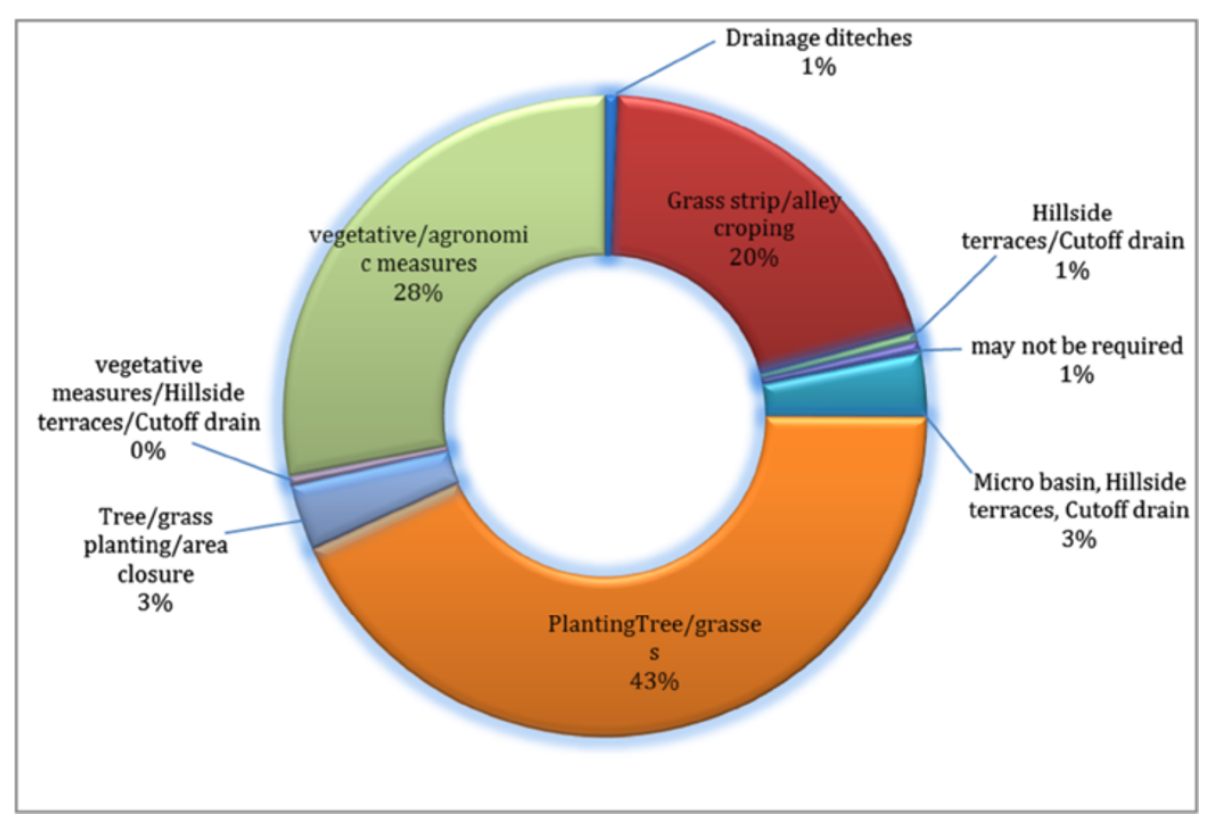

Figure 3 Proportion of support practices.

and/or tree planting. The areas under this category are either woodland of the lowland areas that are under continued risk of deforestation or those highly degraded lands under open grass/shrub/wood lands. In the lowland areas there is less agriculture and human population and area closure/tree planting can go well together with controlling deforestation and illegal settlements. Bench terraces/grass strips are proposed on cultivated lands with moderate to high soil erosion risk and this constitutes $28 \%$ of the Basin area. Bench terraces are less costly as compared to graded structures and are the most widely used in the Ethiopian highlands (Figure 1).

Level bund/level fanya juu is proposed for $6.3 \%$ of the Basin and areas under this category are cultivated fields with low to moderate slope. Graded structures (bunds or Fanya Juu) are suitable for very high soil erosion risk areas under cultivation and this makes up $14 \%$ of the Blue Nile River Basin. Graded structures are mainly useful to stabilize slope and thereby reduce runoff which are the key determinants in soil erosion susceptibility. Areas with extreme slope $(>50 \%)$ are categorized under 'must be changed to forestland/grassland' with area closure. This constitutes 3.3\% of the Basin. Controlled grazing, revegetation and cutoff drain are proposed on open degraded and overgrazed lands which constitutes $8.9 \%$ of the Basin (Table 1).

With all of the proposed major SWC technologies there should be support practices that bring additional benefits to the soil erosion reduction and also add economic benefit to farmers.

\section{Proposed support practices for the major SWC measures} Physical SWC measures are effective in many ways but are often costly and require significant labor investment for construction and maintenance which subsistence farmers often cannot afford. Farmers are reluctant to adopt structures that do not guarantee short term

Table 2 Impacts of SWC measures in reducing soil loss and runoff (Source: Herweg and Ludi 1999)

\begin{tabular}{|c|c|c|c|c|c|c|c|c|c|c|}
\hline \multirow[t]{2}{*}{ Stations } & \multicolumn{5}{|c|}{ Relative impact on soil loss (\%) } & \multicolumn{5}{|c|}{ Relative impact on runoff (\%) } \\
\hline & Graded fanya juu & $\begin{array}{l}\text { Graded } \\
\text { bund }\end{array}$ & $\begin{array}{l}\text { Grass } \\
\text { strip }\end{array}$ & Level fanya juu & $\begin{array}{l}\text { Level } \\
\text { bund }\end{array}$ & Graded fanya juu & $\begin{array}{l}\text { Graded } \\
\text { bund }\end{array}$ & $\begin{array}{l}\text { Grass } \\
\text { strip }\end{array}$ & Level fanya juu & $\begin{array}{l}\text { Level } \\
\text { bund }\end{array}$ \\
\hline Anjeni ( $28 \%$ slope) & -68 & -66 & -72 & - & - & -33 & -32 & -41 & - & - \\
\hline Anjeni ( $12 \%$ slope) & -81 & -63 & -57 & - & - & -50 & -40 & -19 & - & - \\
\hline Andit-Tid & -63 & -41 & -73 & - & - & -2 & -5 & -33 & - & - \\
\hline Maybar & -4 & +73 & -55 & -72 & -37 & -8 & +46 & -33 & - & - \\
\hline Dizi & -91 & -87 & -71 & - & - & -59 & -40 & -57 & - & - \\
\hline Average & -61.4 & -36.8 & -65.6 & - & - & -30.4 & -14.2 & -36.6 & - & - \\
\hline
\end{tabular}




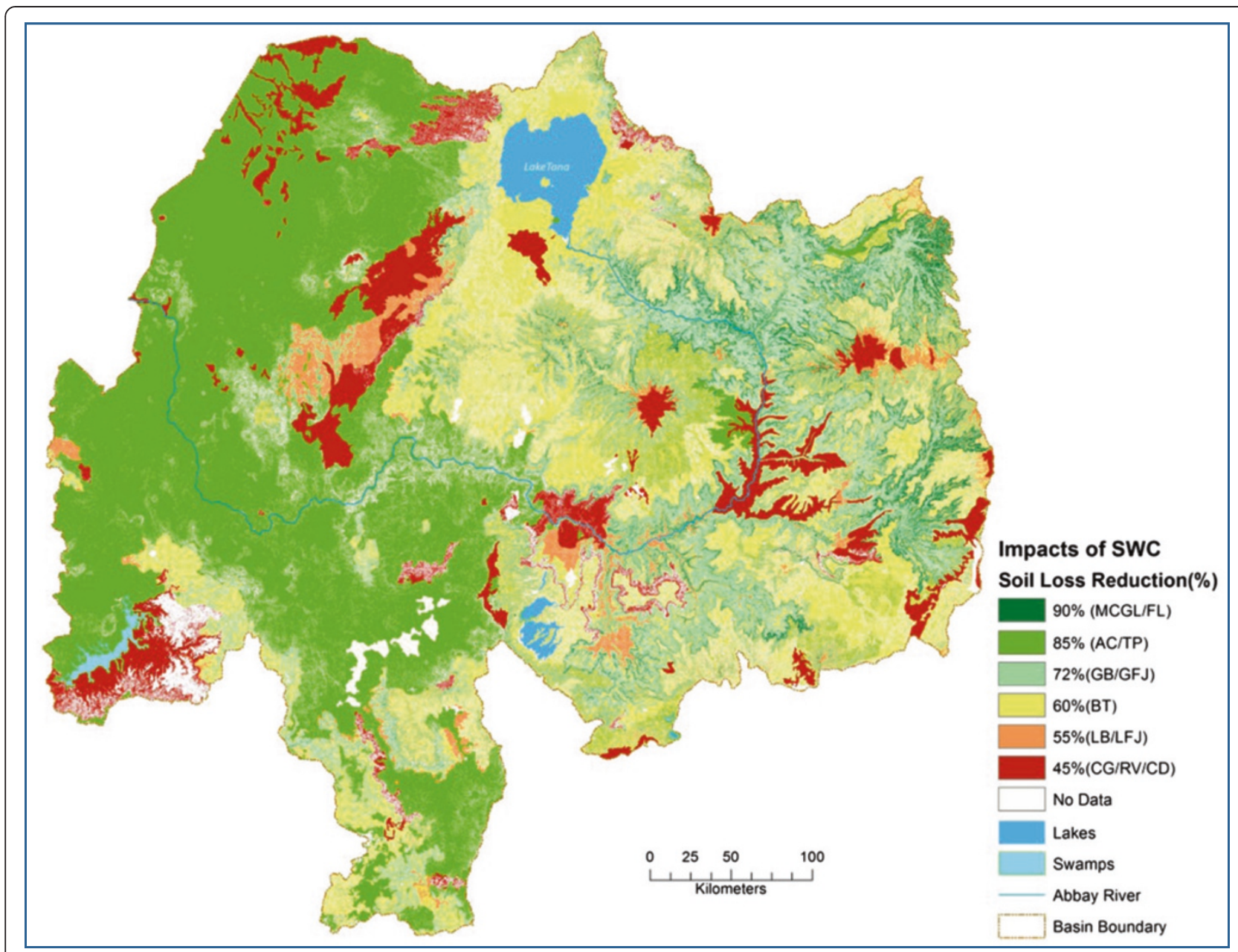

Figure 4 MCGL/FL: must be changed to grassland or forest land; AC/TP-area closure/tree planting; GB/GFJ-graded bund/graded Fanya juu; BT-bench terraces; LB/LFJ-level bund/level Fanya juu; CG/RV/CD-controlled grazing, revegetation, cutoff drain.

economic return; one way of addressing this issue of short term economic gain is by combining measures for example planting fruit trees and other appropriate grass species on structures. This method, in addition to its short term economic benefits, can stabilize the structures, contribute to reducing runoff, increase soil organic

Table 3 Implications of the proposed SWC technologies (Based on model results)

\begin{tabular}{lllll}
\hline $\begin{array}{l}\text { Proposed SWC } \\
\text { measure }\end{array}$ & $\begin{array}{l}\text { \% reduction } \\
\text { in soil loss }\end{array}$ & $\begin{array}{l}\text { Total soil loss } \\
\text { reduction (tons) }\end{array}$ & $\begin{array}{l}\text { Area } \\
\mathbf{( k m}^{2} \mathbf{)}\end{array}$ & $\begin{array}{l}\text { Area } \\
\mathbf{( \% )}\end{array}$ \\
\hline MCGL/FL & 90 & $536,839,200$ & 5,680 & 3.4 \\
AC/TP & 85 & $83,673,700$ & 66,285 & 39.6 \\
GB/GFJ & 72 & $1,074,708,000$ & 24,687 & 14.7 \\
BT & 60 & $274,625,200$ & 43,704 & 26.1 \\
LB/LFJ & 55 & $150,794,900$ & 10,399 & 6.2 \\
CG/RV/CD & 45 & $112,935,500$ & 15,527 & 9.3 \\
No Data* & - & $1,574,825$ & 1,160 & 0.7 \\
\hline
\end{tabular}

*data for estimating\% soil loss reduction is not available. content and provide fodder for livestock. Combining physical measures with agronomic and biological measures make the system more sustainable. These combined methods can strike a balance in addressing the issues of soil erosion in one hand and short term economic return for the farmers on the other. There can be many possible support practices for the major SWC measures and possible actions can be identified that can enhance the efficiency and acceptability of SWC interventions based on the local priorities (Figure 2).

In the lowland areas of the Blue Nile Basin where area closure/tree planting ( $\mathrm{AC} / \mathrm{TP})$ is proposed as a major SWC (43\% of the basin) only further afforestation measures are recommended as a support practice. Soil erosion is minimal in these areas but with the continued deforestation and growing settlements this may change soon. In the cultivated fields where bench terraces $(28 \%$ of the basin) suitable, agronomic/vegetative measures are proposed. In high slope cultivated areas (20\% of the basin) graded structures are suitable with grass strip/ 


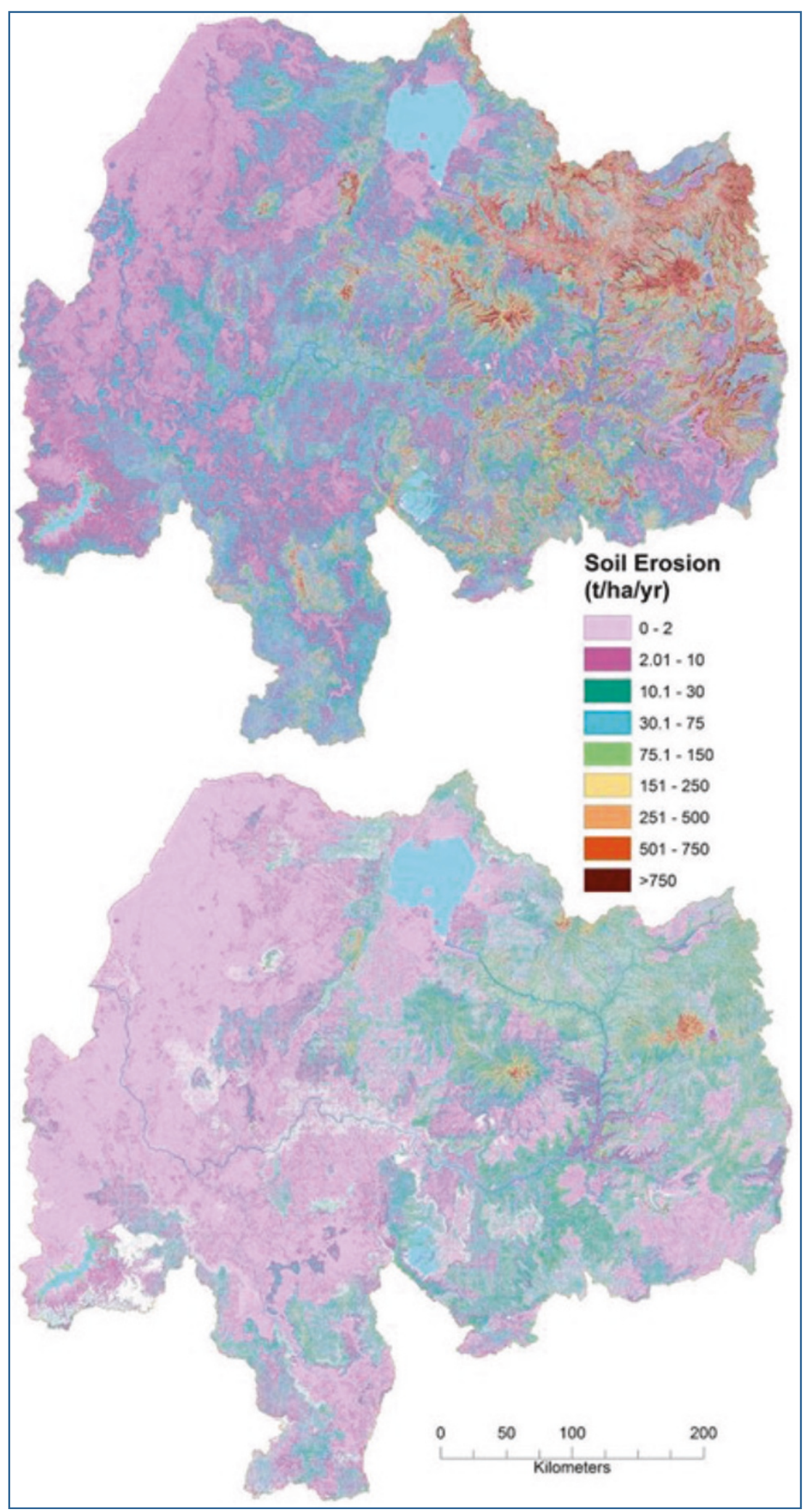

Figure 5 Conservation scenario map ('without' and 'with' SWC intervention). 
alley cropping measures. Area closure with trees and grasses are suitable in areas where land uses change (to forestland/grassland) is proposed (less than $4 \%$ of the basin). In the water stress areas with hills and high slopes where controlled grazing/area closure/revegetation is proposed as a major SWC measure (3\% of the basin), micro basins/hillside terraces and cutoff drains are suitable support practices (Figure 3).

\section{Scenario analysis 'with' and 'without' SWC}

The different SWC technologies have different impacts in terms of reducing runoff and soil loss on one hand and enabling infiltration on the other. In most parts of the basin where precipitation is high $(>1300 \mathrm{~mm})$ the priority of SWC is to conserve soil through the drainage of excess water. In contrast in semi-arid areas where precipitation is less than $500 \mathrm{~mm}$ water conservation is the priority (Mitiku et al. 2006). Soil and water conservation practices significantly reduce land degradation caused by soil erosion and there are studies that have indicated significant reduction of soil loss due to SWC measures. One of such studies is a plot based study on Soil Conservation Research project (SCRP) stations by Herweg and Ludi (1999). They have reported the impacts of the different SWC measures in reducing soil loss and runoff (Table 2).

A comparative field study by Yihenew et al. (2007) demonstrated the difference between conserved and non-conserved land. A 9-year old soil bund, a 9-year soil bund stabilized with tree lucerne, a 9-year old soil bund stabilized with vetiver and a 6-year old soil bund stabilized with tree lucerne had $71.20,68.56,52.30$, and $36.12 \%$, respectively higher percent organic matter than the control treatment. The result agrees with the finding by Million (2003) that organic matter content of three terraced sites with original slopes of 15,25 , and $35 \%$ were higher compared to the corresponding non-terraced sites of similar slope. A study conducted by Kinati (2006) also showed that the organic matter content of non-conserved land for a slope range between 10 and $15 \%$ was lower than the

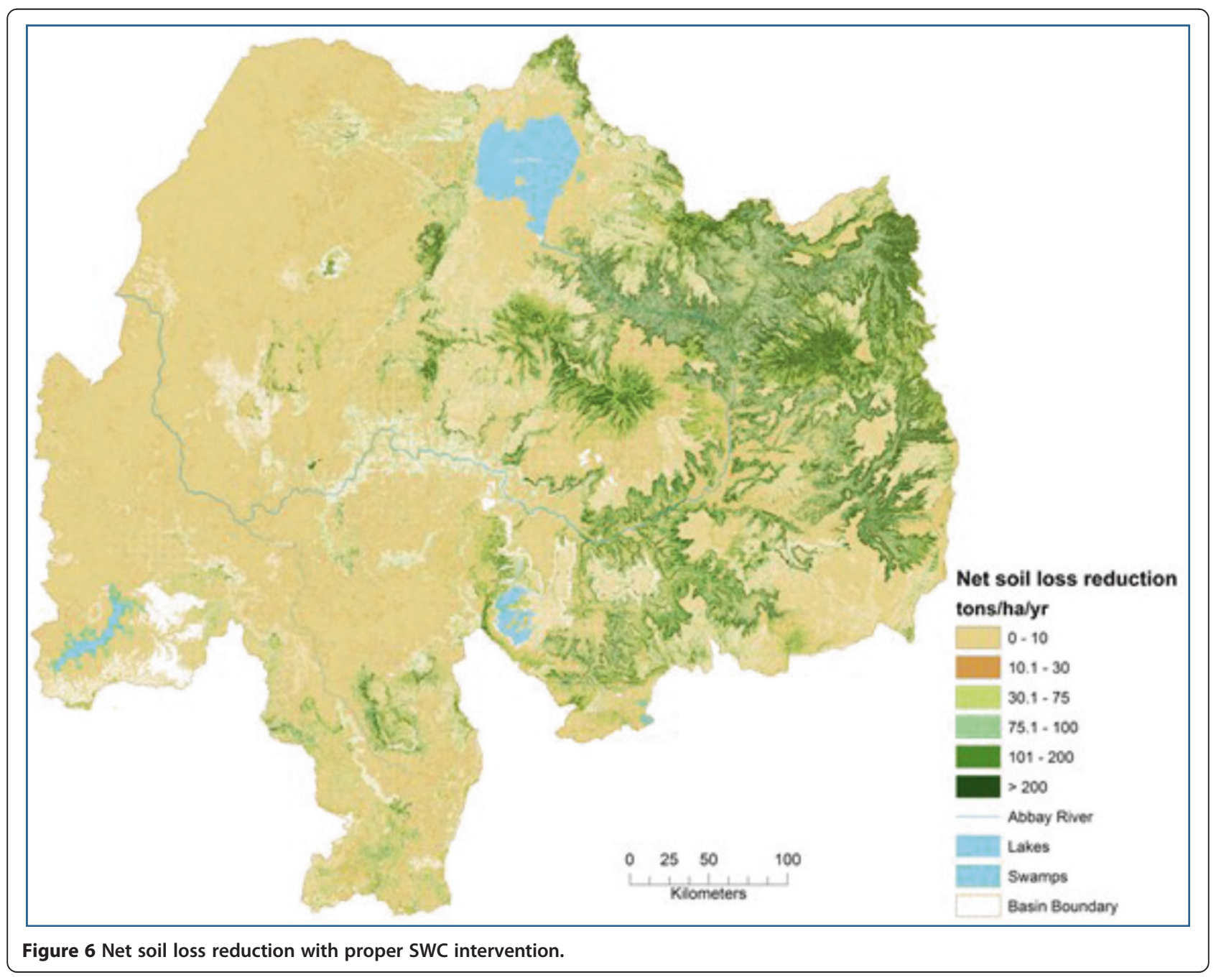


terraced land of corresponding slope class. The practices also had a significant impact on the amount of infiltration. The non-conserved land demonstrated the lowest mean value of infiltration rate. Slope stabilization is also another advantage of SWC techniques.

Potential scenarios at the basin scale are based on these findings and are referred to as options 'with' and 'without' SWC interventions. These scenarios are prepared under two assumptions. The 'with' scenario assumes all the best SWC practices are applied for each homogeneous unit of land, and the 'without' scenario considers the traditional waterways and cutoff drains that have been implemented with minimal effect in reducing soil loss as compared to structural measures (Figure 4, Table 3).

Assuming that these measures are appropriately implemented across the basin soil loss can be reduced by $46 \%$ within 5-10 years, or at an annual rate of $9.2 \%$ (Figure 5).

The Net Soil Erosion (equation 1) has been calculated for each scenario, and indicates that nearly 600 million tons of soil can be protected within 5-10 years of successful SWC intervention. The general assumption in calculating the Net Soil Loss Reduction (NSLR) is that all support practices are implemented successfully and that the community carries on the technologies in the long run. Even with the SWC measures there are areas that will continue to have high soil erosion. Area closure is effective ways for land reclamation but may not be appropriate in the highlands as it incurs huge cost for resettlement of the population. The second alternative to area closure is a combined SWC of structural and biological measures which is the preferred method in this study (Figure 6).

\section{Erosion statistics across administrative zones}

The zonal statistics of the current soil erosion rate without intervention is compared against the 'with' intervention scenario for the administrative zones inside the Basin. This helps to align SWC discussions against practical planning units. Nearly $60 \%$ of the soil loss in the Blue Nile Basin can be prevented with successful implementation of SWC in only four zones (south Wollo, east Gojam, south Gonder and north Shewa (R3; Table 4)). The overall impacts of SWC can significantly reduce soil loss within three to five years of implementation. The 'with' scenario assumes a successful implementation of optimal SWC combinations (physical and biological) that is required for a specific landscape (Figure 7).

In addition to the on-site impacts which occur across the Ethiopian Highlands, siltation of downstream reservoirs is experienced in Sudan and Egypt. This shared problem needs shared interventions amongst these countries to abate the problem of land degradation in the upstream areas of the Blue Nile Basin. If proper SWC interventions are made according to the recommendations it may take 10-15 years to bring the extreme soil erosion to an acceptable level. By this, Ethiopia (now building a mega dam in the downstream of the Blue Nile Basin) and downstream countries (Sudan and Egypt) will benefit as

Table 4 Zonal soil erosion scenario 'with' and 'without' SWC (Based on model results)

\begin{tabular}{|c|c|c|c|c|c|}
\hline Zone name & Without SWC (a) (tons/yr) & With SWC (b) (tons/yr) & Difference $(a-b)$ (tons/yr) & $\%$ Difference $\left(a-b / a^{*} 100\right)$ & $\begin{array}{l}\% \text { share from the } \\
\text { total reduction }\end{array}$ \\
\hline Asosa & $4,561,220$ & 727,195 & $3,834,025$ & 84.1 & 0.2 \\
\hline E. Gojam & $312,840,000$ & $82,538,700$ & $230,301,300$ & 73.6 & 12.2 \\
\hline N. Shewa (R3) & $260,560,000$ & $53,000,600$ & $207,559,400$ & 79.7 & 11.0 \\
\hline W. Gojam & $179,986,000$ & $46,888,900$ & $133,097,100$ & 73.9 & 7.1 \\
\hline S. Gonder & $286,338,000$ & $70,408,100$ & $215,929,900$ & 75.4 & 11.5 \\
\hline N. Gonder & $72,099,900$ & $17,846,200$ & $54,253,700$ & 75.2 & 2.9 \\
\hline Jimma & $17,848,200$ & $3,800,180$ & $14,048,020$ & 78.7 & 0.7 \\
\hline Metekel & $47,884,000$ & $8,075,580$ & $39,808,420$ & 83.1 & 2.1 \\
\hline AgewAwi & $47,856,700$ & $13,003,700$ & $34,853,000$ & 72.8 & 1.8 \\
\hline W. Wellega & $22,836,500$ & $5,421,090$ & $17,415,410$ & 76.3 & 0.9 \\
\hline Illubabor & $23,470,300$ & $6,221,270$ & $17,249,030$ & 73.5 & 0.9 \\
\hline N. Shewa (R4) & $159,876,000$ & $40,168,600$ & $119,707,400$ & 74.9 & 6.4 \\
\hline West Shewa & $164,648,000$ & $40,879,200$ & $123,768,800$ & 75.2 & 6.6 \\
\hline N. Wello & $127,552,000$ & $26,245,000$ & $101,307,000$ & 79.4 & 5.4 \\
\hline S. Wello & $625,894,000$ & $159,265,000$ & $466,629,000$ & 74.6 & 24.8 \\
\hline E. Wellega & $112,829,000$ & $27,436,300$ & $85,392,700$ & 75.7 & 4.5 \\
\hline Kamashi & $21,674,800$ & $1,884,680$ & $19,790,120$ & 91.3 & 1.0 \\
\hline
\end{tabular}




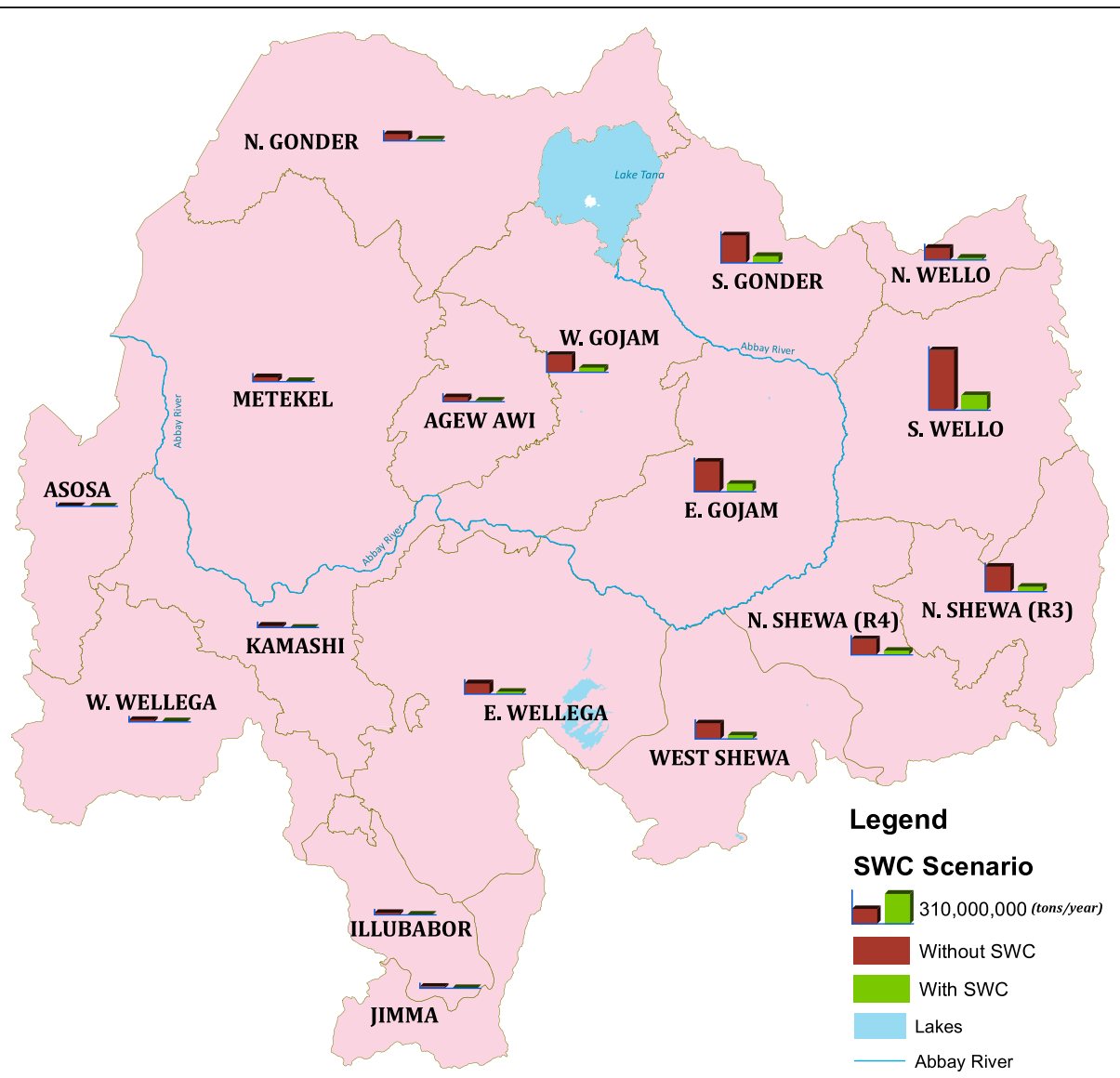

Figure 7 Zonal Statistics with and without SWC measures.

the intervention significantly reduces siltation in the dams and reservoirs.

Finally, discussions of the positive impacts of SWC interventions at administrative zones helps to localize SWC proposals. Any of the administrative zones can consider the SWC recommendations based on the various biophysical criteria.

\section{Conclusions}

In the past the blanket application and 'one size fits all' approach, and top down implementation of SWC interventions have rarely been successful. The application of such interventions in the Blue Nile Basin should consider appropriate biophysical and socioeconomic parameters. In addition any SWC should consider technical feasibility, ecological soundness, economic viability and social acceptance before implementation. The focus of this study was to identify appropriate SWC proposals for the different landscapes of the Blue Nile Basin. Accordingly, soil erosion risk grades, land use/land cover, agroecology and slope are the four major parameters used to create homogeneous planning units to propose appropriate SWC interventions. GIS based raster calculations and overlay functions are used to propose six major SWC proposals.

Bench terraces/grass strips are proposed for 28\% of the areas in the Basin and landscapes under this category include cultivated lands with moderate to high soil erosion risk. Level bund/level fanya-juu is proposed for $6.3 \%$ of the Basin predominantly in dominantly cultivated lands in the humid and sub humid areas that are experience high runoff. Graded structures (bunds or fanya Juu) are proposed for very high soil erosion risk areas under cultivation ( $14 \%$ of the basin). Those areas with extreme slope $(>50 \%)$ are categorized under 'must be changed to forestland/grassland' with area closure and this constitutes $3.3 \%$ of the basin. Controlled grazing, revegetation and cutoff drain is proposed on open degraded and overgrazed lands (8.9\% of the basin). Area closure/tree planting is proposed in $38.9 \%$ of the areas and the areas under this category are either woodland of the lowland areas that are under continued risk of deforestation or those highly degraded lands under open grass/shrub/wood lands. These SWC interventions need to be combined with support practices that can boost the effectiveness of each intervention. 
A plot level study by Herweg and Ludi (1999) on the effectiveness of the major SWC interventions is used to assign soil erosion reduction efficiency for each. Based on these plot level results the 'with' and 'without' SWC scenarios were analyzed and mapped. Results indicate that if the proposed SWC are implemented soil erosion can be reduced by $46 \%$ within five to ten years. The scenarios have also been analyzed for administrative zones. Results indicate that successful implementation of SWC intervention in only four zones (south Wollo, east Gojam, south Gonder and north Shewa (R3)) constitute $60 \%$ of soil loss reduction in the Blue Nile Basin.

The data presented here demonstrate that land degradation (in the form of soil erosion) can be minimized significantly if appropriate and large scale soil and water conservation interventions are carried out, which are tailored to the biophysical setting. The type of proposed intervention needs to be flexible to modify in accordance with local preferences and resource availability during implementation.

\section{Methods}

\section{Location of the study area}

The Blue Nile River Basin (also called Abbay Basin) dominates the Northern highlands of Ethiopia. The Blue Nile River travels some $922 \mathrm{~km}$ from Lake Tana through the mountainous central Ethiopian highlands where it flows through spectacular rugged topography before crossing the Sudan border (ARBIDMPP 1998). The Basin extends from approximately $07^{\circ} 4350^{\prime \prime}$ to $12^{\circ} 45^{\prime} 36^{\prime \prime}$ latitudes and $34^{\circ} 27^{\prime} 29^{\prime \prime}$ to $39^{\circ} 49^{\prime} 45^{\prime \prime}$ longitudes, with a total area of about 200 thousand $\mathrm{km}^{2}$ (See Figure 8).

\section{Data and methods}

Data for soil erosion estimate is adopted from the author's previous work (Amdihun et al. 2014). The land use layer is updated from the ARBIDMP (1998) data at quarter a million scale. SRTM DEM Version 4 is used to calculate slope and agroecology of the Blue Nile Basin. Review of related literature on conservation planning alternatives is explored mainly from Ethiopian Highland Reclamation Study (EHRS 1986), Community Based Participatory Watershed

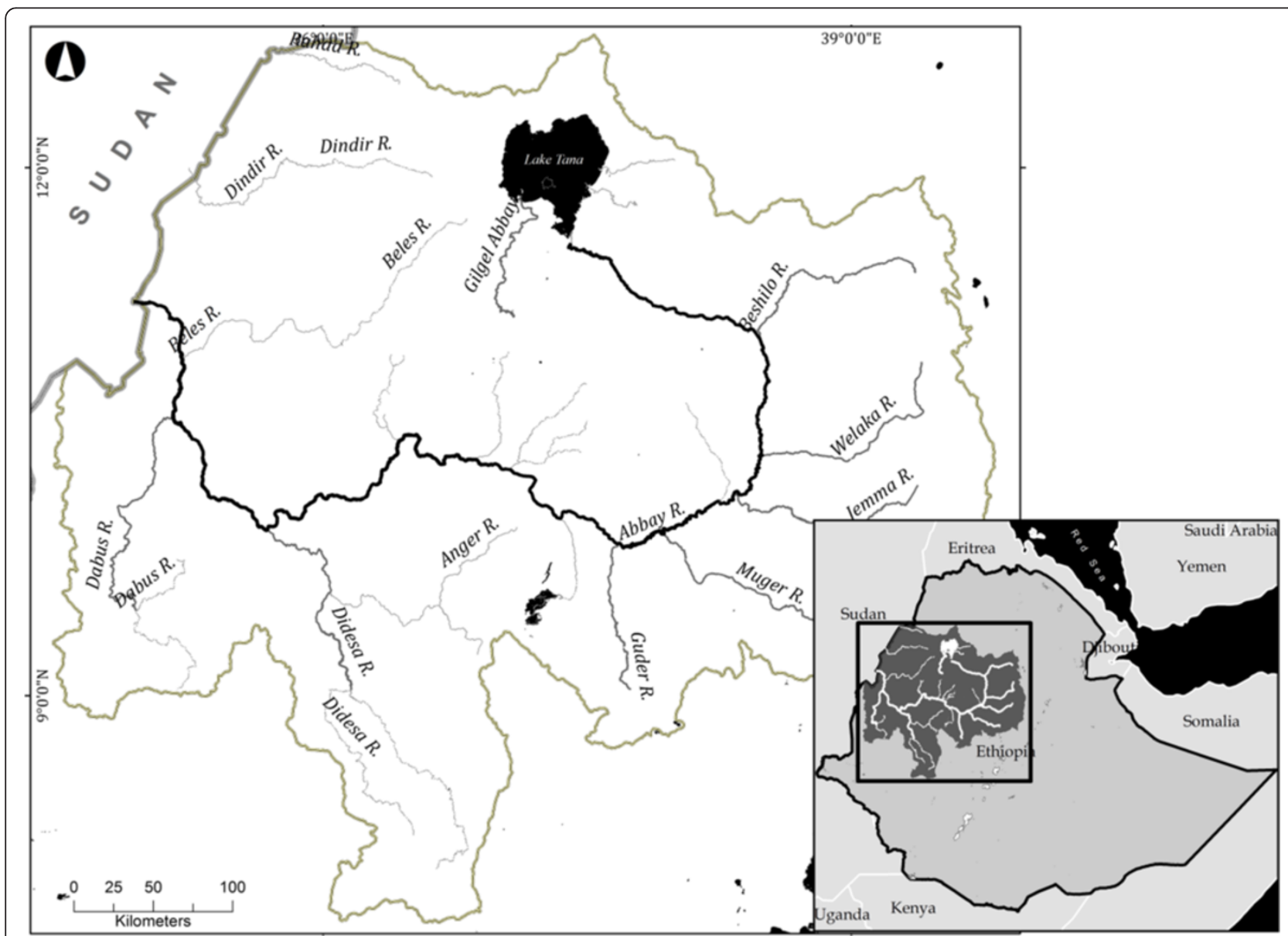

Figure 8 Location map of the Abbay River Basin. 
Management Guideline (CBPWMG) by Lakew et al (2005), Abbay River Basin Integrated Development Master Plan Project (ARBIMPP 1998) document and the different published articles at plot level.
The data layers for the Blue Nile Basin are produced and combined based on the layer combination framework given under Figure 9. Geographic information systems (GIS) based spatial data integration and processing is a

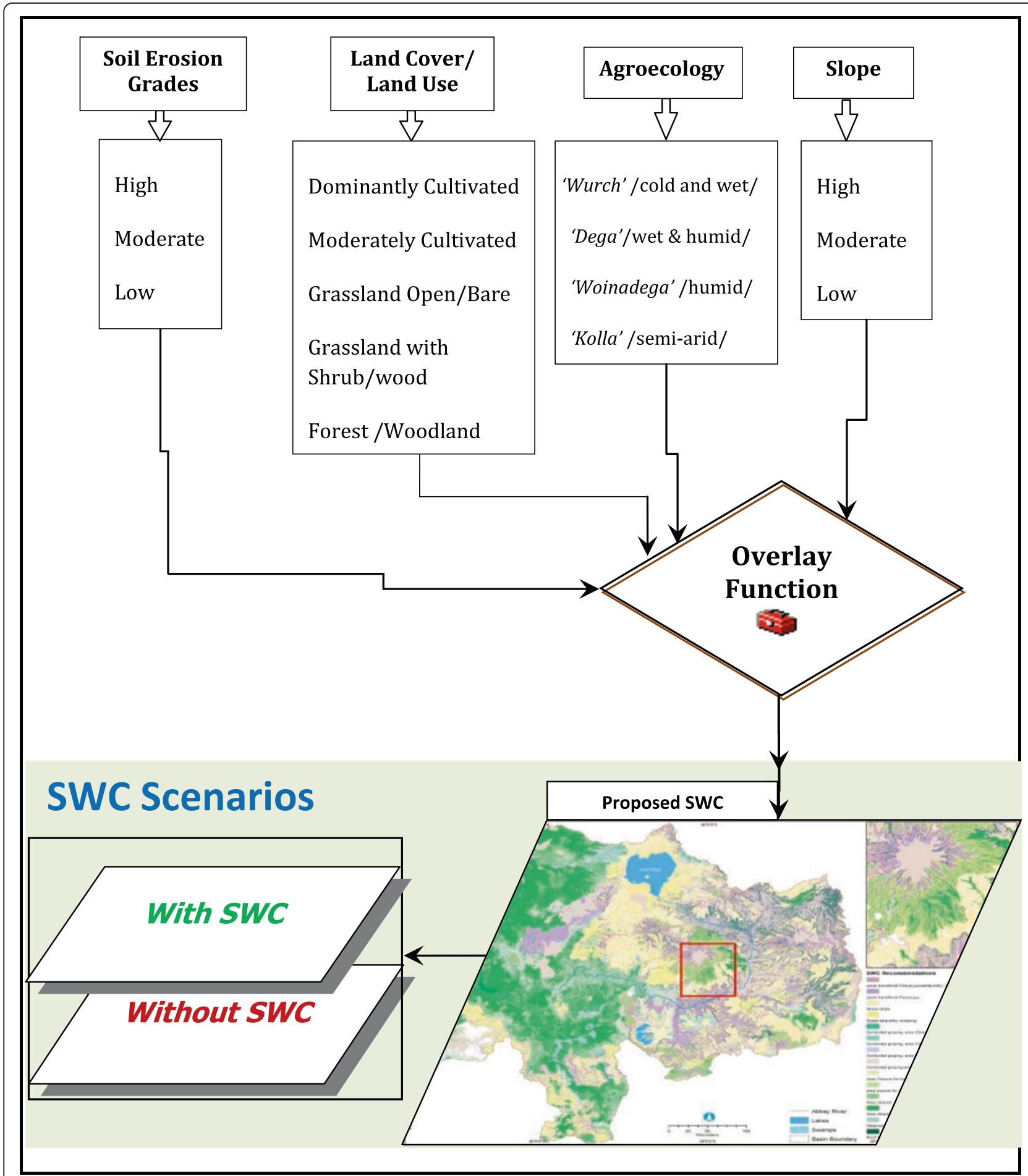

Figure 9 Conceptual frame work for layer combination. 
key method for mapping the different SWC suitability units and scenario analysis. In total 160 different landscape units are identified and these layers are assigned to one of the six major soil and water conservation interventions common in the Ethiopian highlands. For each of these units appropriate SWC measure(s) are attributed and the proposed SWC map is produced.

In line with this findings a Net Soil Loss Reduction (NSLR) is calculated by subtracting the 'without' soil erosion raster from 'with' raster. A pixel to pixel raster calculation is made using the following equation

$$
\text { SLAI }=\text { SLWOI - SLWI }
$$

Where

SLAI = Soil loss after intervention (5-10 years)

SLWOI = Soil loss 'without' SWC intervention

SLWI = Soil loss 'with' SWC intervention

The potential benefits of the major soil and water conservation in terms of reducing soil loss is discussed as the final synthesis of this SWC modeling work based on plot level study results on some of the major SWC measures. The different SWC planning alternatives are proposed and the respective advantages are discussed. Comparative assessments are also made on the 'with' and 'without' SWC scenarios.

The significance of such meso-scale modeling approach is that planners/conservationists do not miss the big picture in the small details like plots. Such multicriteria based planning also helps to come up with comprehensive conservation planning for the landscape that takes the different layers in to planning consideration which are often lacking in the previous conservation interventions of Ethiopia.

The detailed conceptual methodology for data layer combination is given under Figure 9.

\section{Endnotes}

'Derg' means committee referring to the communist regime led by Mengistu Haile Mariam from 1974 to 1987.

\section{Competing interests}

The authors declare that they have no competing interests.

\footnotetext{
Authors' contributions

AA: carried out the research work including the writing of the draft articles, data preparation, manipulation and analysis of the results. He has agreed to be accountable for all aspects of the work in ensuring that questions related to the paper. GE: contributed during the conception and design of the proposal and revising it critically for important intellectual content. He has been supervising the progress of the research. RL: have been involved from the inception of the research concept to proposal development. She also facilitates the funding from IWMI for field work. ZG: contributed in providing guidance starting from the proposal stage of the research commenting critically on the draft paper. He revisited it critically for important intellectual content. He also provided data for test plots of SCRP stations used in the erosion modeling. All authors read and approved the final manuscript.
}

\section{Authors' information}

Ahmed Amdihun is a Lecturer in Addis Ababa University in Geoinformation and Environmental modeling. EphremGebremariam (PhD) is an assistant professor in Addis Ababa University and he is a specialist for Geoinformation and Environmental planning. Rebelo, Lisa-Maria (PhD) is a senior Researcher in International Water Management Institute and specialist for Remote Sensing applications. Gete Zeleke (PhD) is a director and a specialist in soil and water conservation planning.

\section{Acknowledgement}

This research is jointly funded by Addis Ababa University and International Water Management Institute. Special credit goes to supervisors; Dr. Ephrem G., Dr. Lisa-Maria R. and Dr. Gete Z. and their respective institutions for their great contributions in this work. Individual experts all across the Blue Nile (Abbay) Basin also deserve appreciation for their relentless efforts and willingness to travel long distances with me during the field work.

\section{Author details}

${ }^{1}$ Addis Ababa University, EiABC, Chair of CAD and Geo-informatics, P.O. Box 518, Addis Ababa, Ethiopia. ${ }^{2}$ International Water Management Institute (IWMI), Vientiane, Laos. ' ${ }^{3}$ and and Water Resource Center, Addis Ababa, Ethiopia.

Received: 8 April 2014 Revised: 9 April 2014 Accepted: 15 July 2014 Published online: 19 September 2014

\section{References}

Admassie Y (2000) Twenty years to nowhere: property right, and conservation in Ethiopia. Red Sea Press, Lawrenceville, NJ

Amdihun A, Gebremariam E, Rebelo L, Zeleke G (2014) Soil Erosion Modeling in the Abbay (Blue Nile) Basin of Ethiopia: A landscape Approach. Res J Environ Sci, ISSN,1819-3412

ARBIDMPP (1998) Ministry of Water Resources. BCEOM - French Engineering Consultants in association with BRGM and ISL, Addis Ababa, Ethiopia

Bewket W (2003) Land Degradation and Farmers' Acceptance and Adoption of Conservation Technologies in the Digil Watershed, North western Highlands of Ethiopia

CSA (2008) Summary and statistical report of the 2007 population and housing census. Central Statistical Authority, Addis Ababa, Ethiopia

EFAP (1994) Ethiopian Forestry Action Program: The Challenge for Development, vol 2. Ministry of Natural Resource Development and Environmental Protection, Addis Ababa Ethiopia

EHRS (1986) Highland Reclamation Study Final Report. FAO, Rome, Italy

Eleni T (2008) Continued Use of Soil and Water Conservation Practices: a Case study in Tulla District, Ethiopia

Geneletti D (2007) An approach based on spatial multi-criteria analysis to map the nature conservation value of agricultural land. J Environ Manage 83:228-235

Herweg K, Ludi E (1999) The performance of selected soil and water conservation measures - case studies from Ethiopia and Eritrea. CATENA 36:99-114

Hurni H (1997) Concepts of sustainable land management. ICT Journal, The Netherlands

Kassie M, Köhlin G, Randy B (2011) Holden S (2011) Are soil conservation technologies "win-win?". A case study of Anjeni in the north-western Ethiopian highlands. Nat Resour Forum 35:89-99

Kiker GA, Bridges TS, Varghese A, Seager TP, Linkov I (2005) Application of multi-criteria decision analysis in environmental decision making. Integr Environ Assess Manag 1:95-108

Kinati C (2006) The Effect of Integrated Soil and Water Conservation Measures On Soil Physical and Chemical Properties, A Case For EnebsieSarMidirWereda. Mekelle University, Mekelle, Ethiopia. A Thesis Paper

Lakew D, Carucci V, Asrat W-A, Yitayew A (eds) (2005) Community Based Participatory Watershed Development: A Guideline. Ministry of Agriculture and RuralDevelopment, Addis Ababa, Ethiopia

Million A (2003) Characterization of Indigenous Stone bunding (Kab) and its effect on crop yield and soil productivity at Mesobit-Gedba, North Showa Zone of Amhara Region, Thesis. Alemaya University

Mitiku H, Herweg K, Stillhardt B (2006) Sustainable land management: A new approach to soil and water conservation in Ethiopia. Land Resources Management \& Environmental Protection Department, Mekelle University, Ethiopia, Centre for Development and Environment (CDE), National Centre of Competence in Research (NCCR) North-south, Mekelle, Ethiopia 
Nowak P (1987) The Adoption of Agricultural Conservation Technologies: Economic and Diffusion Explanations. Rural Sociol 52(2):208-220

Nyssen J, Poesen J, Moeyerson J, Jozef D, Mitiku H, Andreas L (2004) Human impact on the environment in the Ethiopian and Eritrean highlands-a state of the art. Earth Sci Rev, Science Direct

Prato T, Herath (2007) Multiple-Criteria Decision Analysis for Integrated Catchment Management., School Working Paper - Economic Series 2006, SWP 2006/30

Robert L, Hill M, Hill P, Cresswell H, Dawson S (2007) The Application of a Simple Spatial Multi-Criteria Analysis Shell to Natural Resource Management Decision Making

Shiferaw B, Holden ST (1998) Resource degradation and adoption of land conservation technologies in the Ethiopian highlands: a case study in Andit Tid. Aqric Econ, North Shewa

Wagayehu B, Lars D (2003) Soil and Water Conservation Decision ofSubsistence Farmers in the Eastern Highlands of Ethiopia: a case study ofthe Hunde-Lafto Yihenew G, Tadele A, Mitiku H, Charles Y (2007) Lessons from Upstream Soil Conservation Measures to Mitigate Soil Erosion and its Impact on Upstream and Downstream Users of the Nile River. CP 19 Project workshop proceeding, Ethiopia Zeleke G, Mahmud Y, Björklund G, Köhlin G (2006) Proposal for a Cost-Benefit Framework to Support Pro-SLM Decision-Making in Ethiopia, Environmental Economics Policy Forum for Ethiopia Ethiopian Development Research Institute Addis Ababa Ethiopia

doi:10.1186/s40068-014-0023-9

Cite this article as: Amdihun et al: Suitability and scenario modeling to support soil and water conservation interventions in the Blue Nile Basin, Ethiopia. Environmental Systems Research 2014 3:23.

\section{Submit your manuscript to a SpringerOpen ${ }^{\circ}$ journal and benefit from:}

- Convenient online submission

- Rigorous peer review

- Immediate publication on acceptance

- Open access: articles freely available online

- High visibility within the field

- Retaining the copyright to your article

Submit your next manuscript at $\gg$ springeropen.com 